\title{
Cilostazol induces angiogenesis and regulates oxidative stress in a dose-dependent manner: A chorioallantoic membrane study
}

\author{
Silostazol, doza bağlı bir şekilde anjiyogenezi indükler ve oksidatif stresi düzenler: \\ Bir koryoallantoik membran çalısması
}

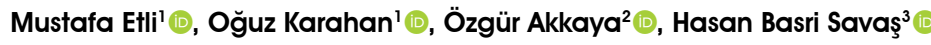 \\ Institution where the research was done: \\ Alanya Alaaddin Keykubat University Faculty of Medicine, Antalya, Turkey
}

Author Affiliations:

Department of Cardiovascular Surgery, Alanya Alaaddin Keykubat University Faculty of Medicine, Antalya, Turkey Department of Cardiovascular Surgery, Alanya Training and Research Hospital, Antalya, Turkey

Department of Biochemistry, Alanya Alaaddin Keykubat University Faculty of Medicine, Antalya, Turkey

\begin{abstract}
Background: In this study, we aimed to investigate the effects of cilostazol on angiogenesis and oxidative stress using the chorioallantoic membrane model.

Methods: In this experimental study, the Ross 308 chick embryos were used. The negative control group $(\mathrm{n}=10)$ received no intervention. The positive control group $(n=10)$ consisted of eggs treated with epidermal growth factor for inducing angiogenesis. Three cilostazol groups were designed with $10^{-7}(\mathrm{n}=10), 10^{-6}(\mathrm{n}=10)$, and $10^{-5}(\mathrm{n}=10) \mathrm{M}$ concentrations. Each egg was punctured on the sixth day of incubation, and drug pellets were introduced to the positive control and drug groups at the prespecified doses. Vascular development was evaluated on the eighth day of application. The total oxidant status, total antioxidant capacity, and oxidative stress index levels were determined from albumen liquids obtained with a syringe before and after drug application.
\end{abstract}

Results: Lower oxidative stress index levels were obtained from the positive control and cilostazol groups compared to the negative control albumens $(\mathrm{p}=0.001)$. The increments in vascular junctions and newly developed vascular nodules were evaluated in drug-free and drug-applied chorioallantoic membranes. The highest activity was obtained in the $10^{-7} \mathrm{M}$ concentration cilostazol group. An increased angiogenic activity was detected in all drug groups in each concentration compared to the negative control group $(\mathrm{p}=0.001)$. Angiogenic activity was similar in all the cilostazol-treated groups $(\mathrm{p}=0.43)$.

Conclusion: Cilostazol has a positive stimulant effect on angiogenesis and it seems to suppress oxidative stress during embryonic growth. Cilostazol exerts these effects significantly and similarly at different doses.

Keywords: Angiogenesis, chorioallantoic membrane model, oxidative stress.
$\ddot{O Z Z}$

Amaç: Bu çalışmada, koryoallantoik membran modelinde silostazolün anjiyogenez ve oksidatif stres üzerine etkileri araştırıldi.

Çalışma planı: Bu deneysel çalışmada, Ross 308 tavuk embriyoları kullanıldı. Negatif kontrol grubuna $(n=10)$ müdahale edilmedi. Pozitif kontrol grubu $(\mathrm{n}=10)$, anjiyogenezi indüklemek için epidermal büyüme faktörü ile muamele edilmiş yumurtalardan oluşuyordu. Üç adet silostazol grubu $10^{-7}(\mathrm{n}=10), 10^{-6}(\mathrm{n}=10)$ ve $10^{-5}(\mathrm{n}=10)$ M konsantrasyon olacak şekilde tasarland. Her bir yumurta inkübasyonun altıncı gününde delinerek, ilaç pelletleri, belirtilen dozlarda pozitif kontrol ve ilaç gruplarına verildi. Uygulamanın sekizinci gününde damar gelişimi değerlendirildi. İlaç uygulamasından önce ve sonra şırınga ile elde edilen albümin sıvılarından total oksidatif durum, total antioksidan kapasite ve oksidatif stres indeksi düzeyleri belirlendi.

Bulgular: Negatif kontrol albüminlerine kıyasla, pozitif kontrol ve silostazol gruplarında daha düşük oksidatif stres indeksi düzeyleri elde edildi $(\mathrm{p}=0.001)$. İlaçsız ve ilaçlı koryoallantoik membranlarda vasküler bağlantılardaki artış ve yeni gelişen vasküler nodüller değerlendirildi. En yüksek aktivite $10^{-7} \mathrm{M}$ konsantrasyonlu silostazol grubunda elde edildi. Negatif kontrol grubu ile karşılaştırıldı ̆̆ında, her konsantrasyonda tüm ilaç gruplarında artmış anjiyojenik aktivite tespit edildi $(\mathrm{p}=0.001)$. Anjiyojenik aktivite silostazol ile tedavi edilen tüm gruplarda benzerdi $(\mathrm{p}=0.43)$.

Sonuç: Silostazol anjiyogenez üzerinde olumlu bir uyarıcı etkiye sahip olup, embriyonik büyüme sırasında oksidatif stresi baskıladığı görülmektedir. Silostazol, bu etkileri farklı dozlarda anlamlı düzeyde ve benzer şekilde göstermektedir.

Anahtar sözcükler: Anjiyogenez, koryoallantoik membran modeli, oksidatif stres.

Received: May 19, 2021 Accepted: August 25, 2021 Published online: October 20, 2021

Correspondence: Oğuz Karahan, MD. Alanya Alaaddin Keykubat Üniversitesi Tıp Fakültesi, Kalp ve Damar Cerrahisi Anabilim Dall, 07425 Alanya, Antalya, Türkiye. Tel: +90 506 - 3929320 e-mail: oguzk2002@gmail.com 
Cilostazol (6-[4-(1-cyclohexyl-1H-tetrazol-5-yl) butoxy]-3,4-dihydro-2(1H)- quinolinone) is a selective and potent phosphodiesterase type 3 (PDE3) inhibitor that intercepts adenosine uptake. ${ }^{[1]}$ It has vasodilatory and antiplatelet activities by preventing the inactivation of cyclic (c) adenosine monophosphate (AMP) (cAMP) in vascular smooth muscle cells and platelets. Therefore, cilostazol is used in the intermittent claudication treatment of patients with peripheral arterial disease. ${ }^{[1,2]}$ Controlled trials have shown that cilostazol treatment in cases of peripheral arterial disease improves both claudication distance and quality of life. ${ }^{[2]}$ More recent reports have indicated that cilostazol has beneficial effects on other ischemic events, such as ischemic stroke. ${ }^{[3]}$ Moreover, this agent has protective effects on endothelial cells and antiproliferative effects on vascular smooth muscle cells. ${ }^{[3,4]}$ Cilostazol is a medical substance used to alleviate intermittent claudication symptoms in patients with peripheral arterial disease. Previous reports have shown that this 2-oxo-quinoline derivative has antithrombotic, vasodilator, antimitogenic, and cardiotonic properties. ${ }^{[1]}$ The effects of cilostazol are based on inhibiting PDE3 activity and preventing cAMP degradation. The PDE enzyme subtypes are located in cells responsible for cardiac and vascular contractility, mainly in the sarcoplasmic reticulum of the heart and smooth muscles of the vascular system. Cilostazol inhibits the catalytic PDE3 subtype, causing elevated levels of cAMP in vessels and platelets. ${ }^{[1,5]}$ An increase in cAMP leads to increasing levels of activated protein kinase A (PKA), which inhibits platelet aggregation. ${ }^{[5]}$ The increase in activated PKA is also responsible for myosin light-chain kinase inactivation, which results in vasodilatation. ${ }^{[5]}$ Recent studies have claimed that cilostazol may have further protective effects on organ systems other than the cardiovascular system, and researches have focused on other mechanistic effects of cilostazol. Amyloid $\beta$ (A $\beta$ ) accumulation causes elevated oxidant levels in cells which, in turn, induces apoptosis. ${ }^{[6]}$ Conversely, the activation of mitogen-activated protein kinases (MAPKs) provokes pathogenic cellular activities, such as apoptosis and transformation. ${ }^{[7]}$

The chorioallantoic membrane (CAM) model is a simple method to evaluate many types of pathophysiological mechanisms. Specifically, recent researches have utilized this model to study inflammatory processes, cytotoxic activities, tumorigenesis, and angiogenesis.$^{[8-10]}$ The advantages of the model are as follows: low cost, no requirement for ethics committee approval, and ease of application. ${ }^{[9]}$ Cardiovascular drugs have been examined using this model to identify their effects on angiogenesis. ${ }^{[10]}$
In the present study, we examined the angiogenic properties of cilostazol using the CAM model and evaluated changes in oxidative stress markers in egg albumen treated with or without cilostazol.

\section{MATERIALS AND METHODS}

Although the CAM model does not require ethics committee approval, all experimental phases were conducted in accordance with the Animal Welfare Act and the Guide for the Care and Use of Laboratory Animals. The Ross 308 chick embryos were used in the study.

All eggs were placed in an incubator with a controlled temperature $\left(37\right.$ to $\left.39^{\circ} \mathrm{C}\right)$ and humidity (80 to $85 \%$ ) for the first six days. Thereafter, $10 \mathrm{~mL}$ of albumen was aspirated with a syringe from a puncture on the bottom side of the eggshell, which provided more space for the embryo. Moreover, this albumen sample was used to measure pre-intervention oxidative stress markers. After the removal of the albumen, the tip of the eggshell was removed with micro-forceps, and the developing embryo was imaged. Eggs without embryos or viable embryos were excluded from the study. Ten viable embryos were allocated to each group. Then, micro-pellets were placed on the embryos, and the eggs were sealed with stretch film and placed back into the incubator. On the eighth day of incubation, the vascular densities of the embryos were evaluated as previously described. ${ }^{[11,12]}$ After the evaluation of vascular development, $5 \mathrm{~mL}$ of albumen was drawn with a syringe to determine post-application oxidative stress markers. Figure 1 shows the study phases.

\section{Grouping and the process of drug delivery}

Egg numbers for each group were determined according to previously described studies. ${ }^{[13]}$

Negative control group $(n=10)$ : No pellet was applied to the embryos, which were used as a reference for normal vascular development.

Positive control group $(n=10)$ : Pellets embedded with $10^{-6} \mathrm{M}$ epidermal growth factor (EGF) [Heberprot-P ${ }^{\circledR}$, Heber Biotec SA., Cuba] were placed on the embryos on the sixth day of incubation, and vascular development was evaluated two days after application.

Drug group $1(n=10)$ : Pellets embedded with $10^{-5} \mathrm{M}$ cilostazol were placed on the embryos on the sixth day of incubation, and vascular development was evaluated two days after application. 

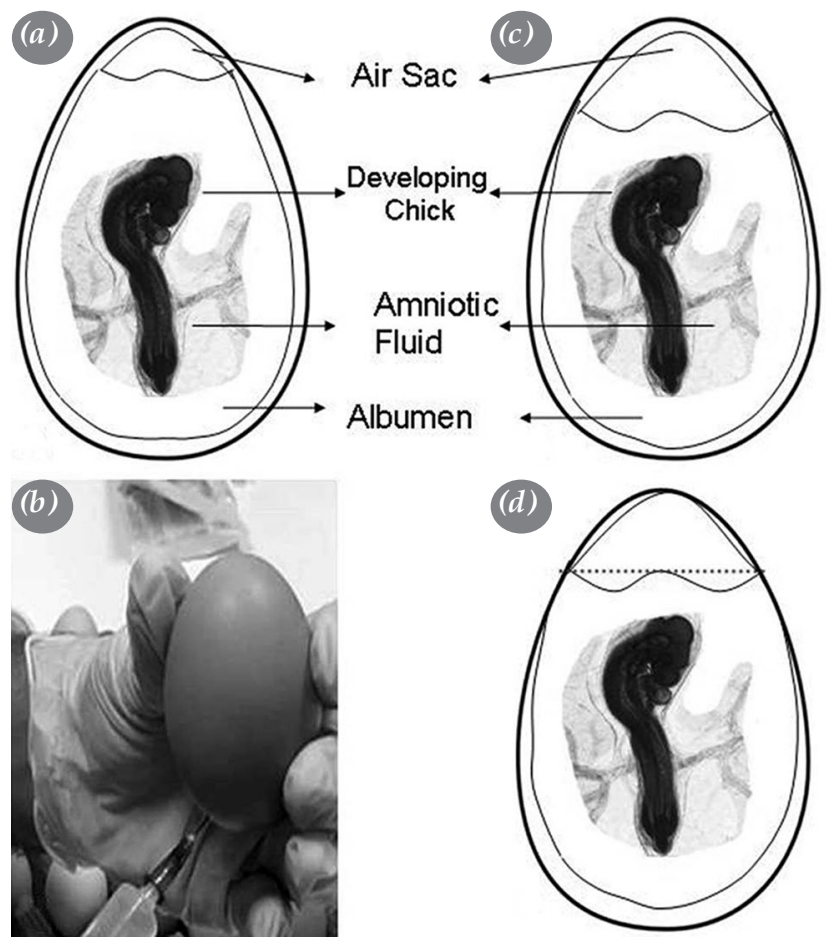

Figure 1. (a) A normal chick egg; embryo, air sack, amniotic fluid, albumen. (b) Removal of albumen via syringe. (c) Enlarged air sack after albumen removal. (d) Removal of egg shell for monitoring embryo development from dashed line.

Drug group $2(n=10)$ : Pellets embedded with $10^{-6} \mathrm{M}$ cilostazol were placed on the embryos on the sixth day of incubation, and vascular development was evaluated two days after application.

Drug group 3 ( $n=10)$ : Pellets embedded with $10^{-7} \mathrm{M}$ cilostazol were placed on the embryos on the sixth day of incubation, and vascular development was evaluated two days after application.

\section{Angiogenesis scoring}

Vascular development of the embryo and the effects of drug-free or drug-embedded pellets on capillary density were evaluated under a stereoscopic microscope. Vessel nodules were scored as described in previous reports. ${ }^{[14]}$ The scoring system involved the evaluation of variation in capillary density on the drug-placed area and the surrounding areas as follows: drug-placed areas were photographed, and the capillary extent was assessed $48 \mathrm{~h}$ after drug application. The formation of new vessels from the main branches of the embryo and the extension of neovascularity were evaluated.

\section{Measurement of oxidative stress markers}

Oxidative stress markers were quantified from the albumen samples drawn pre- and post-application.

Total antioxidant capacity (TAC): The TAC levels were determined according to a previously described method. ${ }^{[15]}$ The method is based on the colorimetric assessment of TAC using a commercially available laboratory kit (Rel Assay Diagnostic, Gaziantep, Turkey). The results were expressed in mmoL Trolox equiv./L.

Total oxidant status (TOS): The TOS levels were determined according to a previously described method. ${ }^{[16]}$ A commercially available laboratory test was used to evaluate the oxidation of $\mathrm{Fe}^{2+}$ ions to $\mathrm{Fe}^{3+}$ ions in an acidic medium. Ferric ions generated a colored complex with xylenol orange, and color intensity was measured colorimetrically. A commercially available laboratory kit (Rel Assay Diagnostic, Gaziantep, Turkey) was used for evaluation. The results were expressed in $\mathrm{mmoL}$ $\mathrm{H}_{2} \mathrm{O}_{2}$ equiv./L. ${ }^{[16]}$

Oxidative stress index (OSI): The OSI values were calculated using the following equation: OSI (arbitrary unit) $=$ TOS $\left(\mathrm{mmoL} \mathrm{H}_{2} \mathrm{O}_{2}\right.$ equiv./L)/TAC (mmoL Trolox equiv./L). ${ }^{[17]}$

\section{Statistical analysis}

The pro-angiogenic effects combined with antioxidant efficacy have not yet been studied systematically in experimental models. Thus, we tested our hypothesis regarding altered concentrations of cilostazol by comparing the previously known angiogenic agent epidermal growth factor. ${ }^{[18]}$ The obtained variables were compared statistically using the SPSS version 15.0 software (SPSS Inc., Chicago, IL, USA). Continuous variables were expressed in mean \pm standard deviation (SD). Between the study groups, oxidative stress markers were compared using the one-way analysis of variance (ANOVA) test, and Tukey's range test was used as a post-hoc test. A $p$ value of $<0.05$ was considered statistically significant.

\section{RESULTS}

To examine the effects of cilostazol on angiogenesis in the CAM method, the number of vascular junctions was determined in two equal-sized rectangular regions of interest (ROI). Initially, the negative control group and the positive control group (treated with epidermal growth factor) were compared to confirm the model (Figure 2). The mean number of branches was significantly higher $(18.9 \pm 6.4$ junctions per ROI) 

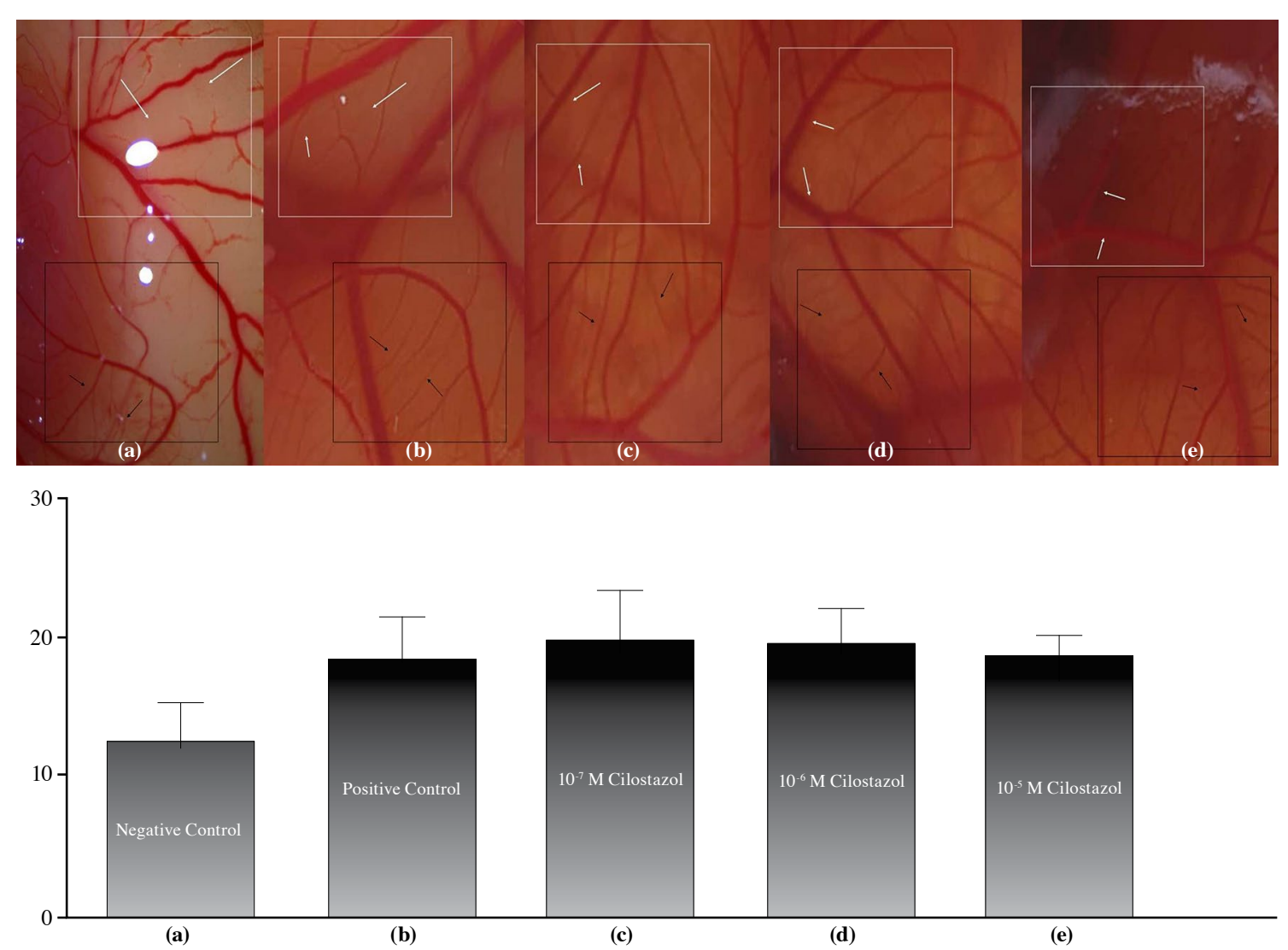

Figure 2. The effects of different concentrations of Cilostazol on CAM model. Positive control group was created with application of epidermal growth factor. Drugs were applied to embryos on the sixth day of incubation and vascular development evaluated in eight-day of application. The angiogenic effects were evaluated by counting the number of vascular junctions and nodules in two rectangular equally sized regions of interest (ROI) (Black and White rectangles), which was significantly $\left({ }^{*} \mathrm{p}<0.05\right)$ higher in groups treated with Cilostazol and epidermal growth factor. Control (a), positive control (b), $10^{-7} \mathrm{M}$ Cilostazol (c), 10-6 M Cilostazol (d), and 10-5 M Cilostazol (e), on day 14 of the experiment. Black arrows: Vessels with multiple nodules and dense junction areas; White arrows: Vessels without nodules or junctions.

in the positive control group than in the negative control group $(13.8 \pm 3.5)(n=10, p=0.01)$. Examination of the cilostazol-treated groups revealed a mean of 19.6 \pm 8.3 junctions per ROI in the $10^{-7} \mathrm{M}$ group, $19.1 \pm 5.2$ junctions per ROI in the $10^{-6} \mathrm{M}$ group, and $18.7 \pm 2.3$ junctions per ROI in the $10^{-5} \mathrm{M}$ group. The
CAM analysis and comparison of the study groups on a scatter plot are presented in Figure 2. The angiogenic activity of cilostazol was found to be statistically significant compared to the negative control group $(\mathrm{p}=0.001)$. However, there was no significant difference between the positive control and the cilostazol-treated

Table 1. The oxidative stress markers of albumen from chick embryos

\begin{tabular}{|c|c|c|c|c|c|c|}
\hline & $\begin{array}{c}\text { Negative } \\
\text { Control Group } \\
(\mathrm{n}=10)\end{array}$ & $\begin{array}{c}\text { Positive } \\
\text { Control Group } \\
(n=10)\end{array}$ & $\begin{array}{c}10^{-5} \text { Cilostazol } \\
\text { Group } \\
(\mathrm{n}=10)\end{array}$ & $\begin{array}{c}10^{-6} \text { Cilostazol } \\
\text { Group } \\
(\mathrm{n}=10)\end{array}$ & $\begin{array}{c}10^{-7} \text { Cilostazol } \\
\text { Group } \\
(\mathrm{n}=10)\end{array}$ & \\
\hline & Mean \pm SD & Mean \pm SD & Mean \pm SD & Mean \pm SD & Mean \pm SD & $p^{*}$ \\
\hline $\mathrm{TOS}\left(\mathrm{mmol} \mathrm{H}_{2} \mathrm{O}_{2} \mathrm{Eq} / \mathrm{L}\right)$ & $3.97 \pm 0.16$ & $2.74 \pm 0.81$ & $2.88 \pm 0.003$ & $2.21 \pm 0.003$ & $1.91 \pm 0.003$ & 0.001 \\
\hline TAC (mmolTroloxEq/L) & $0.86 \pm 0.17$ & $1.27 \pm 0.39$ & $1.69 \pm 0.05$ & $1.61 \pm 0.003$ & $0.93 \pm 0.003$ & 0.001 \\
\hline OSI AU & $4.76 \pm 0.83$ & $2.47 \pm 1.48$ & $1.70 \pm 0.05$ & $1.37 \pm 0.001$ & $2.05 \pm 0.003$ & 0.001 \\
\hline
\end{tabular}

SD: Standard deviation; TOS: Total oxidative status; TAC: Total antioxidant capacity; OSI: Oxidative stress index; AU: Arbitrary unit; * p<0.05 indicates statistical significance. 
Table 2. The comparison of oxidative markers between groups (Tukey's Honestly Significant Difference)

\begin{tabular}{|c|c|c|c|c|}
\hline Markers & Groups & & Mean \pm SD & $p^{*}$ \\
\hline \multirow{9}{*}{ 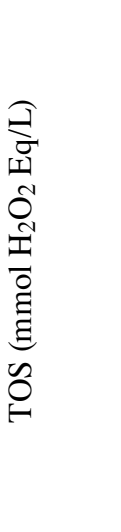 } & \multirow{3}{*}{$10^{-5}$ Cilostazol Group $(n=10)$} & $10^{-6}$ Cilostazol & $2.21 \pm 0.003$ & 0.001 \\
\hline & & $10^{-7}$ Cilostazol & $1.91 \pm 0.003$ & 0.001 \\
\hline & & Control & $3.97 \pm 0.16$ & 0.001 \\
\hline & \multirow{3}{*}{$10^{-6}$ Cilostazol Group $(n=10)$} & $10^{-5}$ Cilostazol & $2.88 \pm 0.003$ & 0.001 \\
\hline & & $10^{-7}$ Cilostazol & $1.91 \pm 0.003$ & 0.001 \\
\hline & & Control & $3.97 \pm 0.16$ & 0.001 \\
\hline & \multirow{3}{*}{$10^{-7}$ Cilostazol Group $(\mathrm{n}=10)$} & $10^{-5}$ Cilostazol & $2.88 \pm 0.003$ & 0.001 \\
\hline & & $10^{-6}$ Cilostazol & $2.21 \pm 0.003$ & 0.001 \\
\hline & & Control & $3.97 \pm 0.16$ & 0.001 \\
\hline \multirow{9}{*}{ 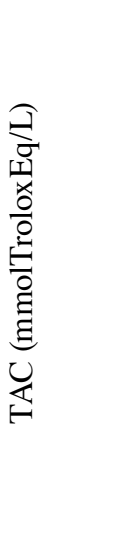 } & \multirow{3}{*}{$10^{-5}$ Cilostazol Group $(\mathrm{n}=10)$} & $10^{-6}$ Cilostazol & $1.61 \pm 0.003$ & 0.145 \\
\hline & & $10^{-7}$ Cilostazol & $0.93 \pm 0.003$ & 0.001 \\
\hline & & Control & $0.86 \pm 0.17$ & 0.001 \\
\hline & \multirow{3}{*}{$10^{-6}$ Cilostazol Group $(\mathrm{n}=10)$} & $10^{-5}$ Cilostazol & $1.69 \pm 0.05$ & 0.145 \\
\hline & & $10^{-7}$ Cilostazol & $0.93 \pm 0.003$ & 0.001 \\
\hline & & Control & $0.86 \pm 0.17$ & 0.001 \\
\hline & \multirow{3}{*}{$10^{-7}$ Cilostazol Group $(n=10)$} & $10^{-5}$ Cilostazol & $1.69 \pm 0.05$ & 0.001 \\
\hline & & $10^{-6}$ Cilostazol & $1.61 \pm 0.003$ & 0.001 \\
\hline & & Control & $0.86 \pm 0.17$ & 0.364 \\
\hline \multirow{9}{*}{$\begin{array}{l}\stackrel{\vartheta}{\varangle} \\
\overline{\mathscr{2}} \\
0\end{array}$} & \multirow{6}{*}{$10^{-6}$ Cilostazol Group $(n=10)$} & $10^{-6}$ Cilostazol & $1.37 \pm 0.001$ & 0.316 \\
\hline & & $10^{-7}$ Cilostazol & $2.05 \pm 0.003$ & 0.238 \\
\hline & & Control & $4.76 \pm 0.83$ & 0.001 \\
\hline & & $10^{-5}$ Cilostazol & $1.70 \pm 0.05$ & 0.316 \\
\hline & & $10^{-7}$ Cilostazol & $2.05 \pm 0.003$ & 0.004 \\
\hline & & Control & $4.76 \pm 0.83$ & 0.001 \\
\hline & \multirow{3}{*}{$10^{-7}$ Cilostazol Group $(n=10)$} & $10^{-5}$ Cilostazol & $1.70 \pm 0.05$ & 0.238 \\
\hline & & $10^{-6}$ Cilostazol & $1.37 \pm 0.001$ & 0.004 \\
\hline & & Control & $4.76 \pm 0.83$ & 0.001 \\
\hline
\end{tabular}

SD: Standard deviation; TOS: Total oxidative status; TAC: Total antioxidant capacity; OSI: Oxidative stress index; AU: Arbitrary unit; ${ }^{*} \mathrm{p}<0.05$ indicates statistical significance.

groups in terms of the incremental vascular junctions and newly developed vascular nodules in the CAM model $(\mathrm{p}=0.51)$. The highest angiogenic activity was observed in the group treated with $10^{-7} \mathrm{M}$ cilostazol, while the drug-administered groups were statistically similar compared to each other $(p=0.43)$.
Significantly lower OSI values were present in the groups treated with epidermal growth factor (positive control) and cilostazol compared to the negative control group $(\mathrm{p}<0.05)$. The lowest OSI values were observed in the $10^{-6} \mathrm{M}$ cilostazol group. The highest TOS levels were detected during normal embryonic 
growth in the negative control group. The TOS levels were significantly reduced in the groups treated with epidermal growth factor and cilostazol, compared to the negative control group $(\mathrm{p}<0.05)$. The highest TAC levels were observed in the $10^{-5} \mathrm{M}$ cilostazol group. The comparison of the TOS, TAC, and OSI values between the groups is presented in Table 1 . Significantly lower levels of oxidative stress and higher levels of antioxidant capacity were found in all cilostazol-treated groups, compared to those in the negative control group (Table 2).

\section{DISCUSSION}

Our study results showed that cilostazol promoted angiogenesis in the CAM model. Moreover, oxidative stress markers were reduced in cilostazol-treated chick embryos. To the best of our knowledge, this study is the first to investigate oxidative stress in the albumen and to assess angiogenesis in the CAM model. The different doses of cilostazol used in this study had similar effects on angiogenesis and oxidative stress.

A comprehensive investigation of the angiogenic properties of substances requires complex animal models or other in vivo strategies. However, these complex models require advanced laboratory infrastructure, expensive equipment, extended testing time, and multiple animal sacrifices. ${ }^{[19-21]}$ The CAM is a reference model for the evaluation of developmental angiogenesis due to the accessibility and programmability of every stage of development. In this model, testing materials are usually prepared in soluble form and planted on the highly vascularized membrane for the evaluation of pro-angiogenic or anti-angiogenic potentials. ${ }^{[22,23]}$ After incubation of chick eggs, primitive embryonic vessel formations develop in the initial $42 \mathrm{~h}$, and vasculogenesis begins. Yolk sac-derived mesodermal angioblasts are responsible for the formation of this primitive structure, consisting of a simple endothelium, erythrocytes, and plasma and is activated within the first $48 \mathrm{~h}$. After Day 10, as the vascular system matures, growth factors decrease, and accelerated vasculogenesis terminates. This highly increased vessel formation is essential for embryo growth and the regulation of optimal metabolic activity. ${ }^{[19,22-24]}$ Previous studies have shown that the external addition of growth factors, including EGF, promotes angiogenesis. ${ }^{[18]}$ Moreover, EGF positively increases the capillary network. ${ }^{[25]}$ Based on these findings, we created a CAM model with additional EGF to observe the induced angiogenesis together with the routine angiogenesis process. Angiogenesis was evaluated in the first eight days, and the evaluation was made during the most intense period of vasculogenesis. As expected, the EGF-added group showed significantly increased angiogenesis compared to the control group.

In a previous study, cilostazol was found to increase collateral blood flow and vascularity in a vascular endothelial growth factor (VEGF)dependent manner. ${ }^{[26]}$ Sanada et al. ${ }^{[27]}$ reported that this angiogenesis-stimulating effect could be related to hepatocyte growth factor induction via cAMP and peroxisome proliferator-activated receptor-gamma $(\gamma)$ pathways. Oguchi et al. ${ }^{[28]}$ demonstrated that cilostazol prevented $A \beta$-induced cytotoxicity and suppressed MAPK activation, suggesting that cilostazol could have a potential role in reducing oxidative stress through these pathways. Furthermore, cilostazol was proposed as a cellular protective agent against oxidative damage in other studies that investigated other cell types, such as testicular and neuronal cells. $^{[29,30]}$ Although the exact mechanism has not been fully understood yet, it has been demonstrated that cilostazol has regulatory effects on plasma lipoproteins by decreasing plasma triglycerides and increasing high-density lipoprotein cholesterol. ${ }^{[31]}$ Similar to previous reports, our results showed that cilostazol had antioxidant effects. Recent studies have investigated the effects of cilostazol on angiogenesis based on the beneficial properties reported previously. In a cell culture and experimental mouse model study, Tseng et al.$^{[32]}$ found that cilostazol ameliorated hyperglycemia-induced endothelial dysfunction and promoted vasculogenesis. They claimed that cilostazol showed this effect by activating AMP-activated protein kinase/acetyl-coenzyme A carboxylase-dependent pathways and cAMP/PKA-dependent pathways. Moreover, an increase in circulating $\mathrm{CD} 34^{+}$cell populations was observed in cilostazol-treated subjects. ${ }^{[32]}$ In Sanada et al.'s ${ }^{[27]}$ study, improved angiogenesis was detected in a mouse ischemic hindlimb model. Similarly, increased angiogenesis and induced cell proliferation through cAMP activation were detected in the rat myocardial ischemia-reperfusion model. ${ }^{[33]}$ In another experimental hindlimb ischemia study, Paronis et al. ${ }^{[34]}$ investigated immune responses, such as interleukin (IL)-2, IL-4, IL-6, IL-10, IL-17A, tumor necrosis factor-alpha, and interferon- $\gamma$ concentrations, in cilostazol-treated rats and found that cilostazol promoted anti-inflammatory cytokine production and induced postoperative angiogenesis. The present study is the first CAM model study to investigate physiological development of embryos treated with cilostazol. Consistent with the literature, 
our results support the idea that cilostazol promotes angiogenesis and reduces oxidative stress. Moreover, cilostazol stimulates angiogenesis, at least as EGF. This study is also the first comparative investigation of the angiogenic properties of cilostazol in different doses, showing that cilostazol has pro-angiogenic potential in $10^{-7}, 10^{-6}$, and $10^{-5} \mathrm{M}$ concentrations.

Nonetheless, some potential limitations to these preliminary results that primarily stem from the methodology and experimental design need to be addressed. First, all results were obtained from the in ovo CAM model that involves embryological angiogenesis, which is different from previously described ischemia-reperfusion models. Second, due to the nature of the experimental design, these results should be confirmed in human subjects.

In conclusion, cilostazol showed antioxidant properties by reducing oxidative stress and increasing antioxidant capacity. The angiogenic activity was found to be similar in all cilostazol-treated groups. Additionally, stronger angiogenesis was observed in cilostazol-treated chorioallantoic membranes. Understanding the exact mechanism of action is potentially useful for implementing new treatment modalities. The beneficial effects of cilostazol should be investigated in other ischemia-induced models other than the hindlimb ischemia model.

\section{Declaration of conflicting interests}

The authors declared no conflicts of interest with respect to the authorship and/or publication of this article.

\section{Funding}

The authors received no financial support for the research and/or authorship of this article.

\section{REFERENCES}

1. Schrör K. The pharmacology of cilostazol. Diabetes Obes Metab 2002;4 Suppl 2:S14-9.

2. Robless P, Mikhailidis DP, Stansby GP. Cilostazol for peripheral arterial disease. Cochrane Database Syst Rev 2008;(1):CD003748.

3. Huang Y, Cheng Y, Wu J, Li Y, Xu E, Hong Z, et al. Cilostazol as an alternative to aspirin after ischaemic stroke: A randomised, double-blind, pilot study. Lancet Neurol 2008;7:494-9.

4. Rybalkin SD, Rybalkina I, Beavo JA, Bornfeldt KE. Cyclic nucleotide phosphodiesterase 1C promotes human arterial smooth muscle cell proliferation. Circ Res 2002;90:151-7.

5. Balinski AM, Preuss CV. Cilostazol. [Updated 2020 Sep 28]. In: StatPearls [Internet]. Treasure Island (FL): StatPearls Publishing; 2020 Jan-. Available at: https://www.ncbi.nlm. nih.gov/books/NBK544363/

6. Ding H, Wang H, Zhao Y, Sun D, Zhai X. Protective effects

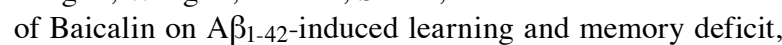

oxidative stress, and apoptosis in rat. Cell Mol Neurobiol 2015;35:623-32.

7. Kim EK, Choi EJ. Compromised MAPK signaling in human diseases: An update. Arch Toxicol 2015;89:867-82.

8. Nowak-Sliwinska P, Segura T, Iruela-Arispe ML. The chicken chorioallantoic membrane model in biology, medicine and bioengineering. Angiogenesis 2014;17:779-804.

9. Kunz P, Schenker A, Sähr H, Lehner B, Fellenberg J. Optimization of the chicken chorioallantoic membrane assay as reliable in vivo model for the analysis of osteosarcoma. PLoS One 2019;14:e0215312.

10. Karahan O, Yavuz C, Demirtas S, Caliskan A, Atahan E. The investigation of the antiangiogenic potential of amiodarone $\mathrm{HCl}$ in the chick embryo chorioallantoic membrane model. Biomedical Research 2013;24:131-4.

11. Ribatti D. Chick embryo chorioallantoic membrane as a useful tool to study angiogenesis. Int Rev Cell Mol Biol 2008;270:181-224.

12. Joimel U, Gest C, Soria J, Pritchard LL, Alexandre J, Laurent $\mathrm{M}$, et al. Stimulation of angiogenesis resulting from cooperation between macrophages and MDA-MB-231 breast cancer cells: Proposed molecular mechanism and effect of tetrathiomolybdate. BMC Cancer 2010;10:375.

13. Baharara J, Amini E, Mousavi M. The anti-proliferative and anti-angiogenic effect of the methanol extract from brittle star. Rep Biochem Mol Biol 2015;3:68-75.

14. Winter R, Dungel P, Reischies FMJ, Rohringer S, Slezak $\mathrm{P}$, Smolle C, et al. Photobiomodulation (PBM) promotes angiogenesis in-vitro and in chick embryo chorioallantoic membrane model. Sci Rep 2018;8:17080.

15. Savran M, Ozmen O, Erzurumlu Y, Savas HB, Asci S, Kaynak M. The impact of prophylactic lacosamide on LPSinduced neuroinflammation in aged rats. Inflammation 2019;42:1913-24.

16. Savran M, Asci H, Ozmen O, Erzurumlu Y, Savas $\mathrm{HB}$, Sonmez $\mathrm{Y}$, et al. Melatonin protects the heart and endothelium against high fructose corn syrup consumptioninduced cardiovascular toxicity via SIRT-1 signaling. Hum Exp Toxicol 2019;38:1212-23.

17. Savran M, Aslankoc R, Ozmen O, Erzurumlu Y, Savas $\mathrm{HB}$, Temel EN, et al. Agomelatine could prevent brain and cerebellum injury against LPS-induced neuroinflammation in rats. Cytokine 2020;127:154957.

18. Ribatti D, Vacca A, Ranieri G, Sorino S, Roncali L. The chick embryo chorioallantoic membrane as an in vivo wound healing model. Pathol Res Pract 1996;192:1068-76.

19. Merckx G, Tay H, Lo Monaco M, van Zandvoort M, De Spiegelaere W, Lambrichts I, et al. Chorioallantoic membrane assay as model for angiogenesis in tissue engineering: Focus on stem cells. Tissue Eng Part B Rev 2020;26:519-39.

20. Yu J, Dardik A. A murine model of hind limb ischemia to study angiogenesis and arteriogenesis. Methods Mol Biol 2018;1717:135-43.

21. Limbourg A, Korff T, Napp LC, Schaper W, Drexler H, Limbourg FP. Evaluation of postnatal arteriogenesis and angiogenesis in a mouse model of hind-limb ischemia. Nat Protoc 2009;4:1737-46. 
22. Maksimov VF, Korostyshevskaya IM, Kurganov SA. Functional morphology of chorioallantoic vascular network in chicken. Bull Exp Biol Med 2006;142:367-71.

23. Kurz H, Ambrosy S, Wilting J, Marmé D, Christ B. Proliferation pattern of capillary endothelial cells in chorioallantoic membrane development indicates local growth control, which is counteracted by vascular endothelial growth factor application. Dev Dyn 1995;203:174-86.

24. Patan S, Haenni B, Burri PH. Implementation of intussusceptive microvascular growth in the chicken chorioallantoic membrane (CAM): 1. pillar formation by folding of the capillary wall. Microvasc Res 1996;51:80-98.

25. Kemp SS, Aguera KN, Cha B, Davis GE. Defining endothelial cell-derived factors that promote pericyte recruitment and capillary network assembly. Arterioscler Thromb Vasc Biol 2020;40:2632-48.

26. Biscetti F, Pecorini G, Straface G, Arena V, Stigliano E, Rutella $\mathrm{S}$, et al. Cilostazol promotes angiogenesis after peripheral ischemia through a VEGF-dependent mechanism. Int J Cardiol 2013;167:910-6.

27. Sanada F, Kanbara Y, Taniyama Y, Otsu R, Carracedo M, Ikeda-Iwabu Y, et al. Induction of angiogenesis by a type III phosphodiesterase inhibitor, Cilostazol, through activation of peroxisome proliferator-activated receptor- $\gamma$ and cAMP pathways in vascular cells. Arterioscler Thromb Vasc Biol 2016;36:545-52.

28. Oguchi T, Ono R, Tsuji M, Shozawa H, Somei M, Inagaki $M$, et al. Cilostazol suppresses $A \beta$-induced neurotoxicity in SH-SY5Y cells through inhibition of oxidative stress and
MAPK signaling pathway. Front Aging Neurosci 2017;9:337.

29. Mohamed MZ, Hafez HM, Zenhom NM, Mohammed HH. Cilostazol alleviates streptozotocin-induced testicular injury in rats via PI3K/Akt pathway. Life Sci 2018;198:136-42.

30. Kim SM, Jung JM, Kim BJ, Lee JS, Kwon SU. Cilostazol mono and combination treatments in ischemic stroke: An updated systematic review and meta-analysis. Stroke 2019;50:3503-11.

31. Elam MB, Heckman J, Crouse JR, Hunninghake DB, Herd JA, Davidson M, et al. Effect of the novel antiplatelet agent cilostazol on plasma lipoproteins in patients with intermittent claudication. Arterioscler Thromb Vasc Biol 1998;18:1942-7.

32. Tseng SY, Chao TH, Li YH, Liu PY, Lee CH, Cho $\mathrm{CL}$, et al. Cilostazol improves high glucose-induced impaired angiogenesis in human endothelial progenitor cells and vascular endothelial cells as well as enhances vasculoangiogenesis in hyperglycemic mice mediated by the adenosine monophosphate-activated protein kinase pathway. J Vasc Surg 2016;63:1051-62.e3.

33. Li J, Xiang X, Xu H, Shi Y.Cilostazol promotes angiogenesis and increases cell proliferation after myocardial ischemiareperfusion injury through a cAMP-dependent mechanism. Cardiovasc Eng Technol 2019;10:638-47.

34. Paronis E, Katsimpoulas M, Kadoglou NPE, Provost C, Stasinopoulou M, Spyropoulos C, et al. Cilostazol mediates immune responses and affects angiogenesis during the acute phase of hind limb ischemia in a mouse model. J Cardiovasc Pharmacol Ther 2020;25:273-85. 